TOMASZ MichaŁ KORCZYŃSKI

Cardinal Stefan Wyszyński University in Warsaw, Poland

\title{
The Genesis of Unblack Metal AND ITS CONTEMPORARY RECEPTION. Cognitive Prospects
}

\section{GENEZA UNBLACK METALU I JEJ WSPÓŁCZESNA RECEPCJA. PERSPEKTYWY POZNAWCZE}

\begin{abstract}
The social and cultural phenomenon of the musical subgenre unblack metal (UBM) is analysed and presented in the paper. The paper aims to highlight the most important aspects and ideological content as a part of content analysis of the musical works by selected UBM bands that represent all three waves of this musical genre. This paper is a first step towards creation of the consistent UBM image to present it in the Polish academic environment. It is a good start for further advanced research to be developed in the future. Several methodological problems that were encountered during research were presented before the analysis of UBM phenomenon. In the paper there is an outline of the UBM history, its ideological foundations that can be found in the musical works of the most important bands from the mid-90-ties until today, the author's vision of the UBM three waves and preliminary content systematisation with thematic sections with the accent on the stylistic efforts and language. UBM texts concern mainly Bible, both Old and New Testaments, but that does not mean that UMB texts are narrowed down to the religious content only. I emphasised eleven thematic sections, several dozens expressions and propaganda mechanisms that have been used. The main conclusion concerns general deficit of the Christian metal research in sociology of music. The paper therefore represents significant research value as a sound introduction into this barely explored issue.
\end{abstract}




\section{STRESZCZENIE}

$\mathrm{W}$ artykule podjęto się analizy społeczno-kulturowego fenomenu, jakim jest podgatunek muzyczny unblack metal (UBM). Głównym celem artykułu było wyeksponowanie najważniejszych akcentów i treści ideologicznych w ramach analizy zawartości treści utworów muzycznych wylosowanych zespołów UBM, które reprezentują wszystkie trzy fale tego gatunku muzycznego.

Artykuł jest pierwszym narzędziem, które pomogło w stworzeniu spójnego obrazu UBM w celu zaprezentowania tego zjawiska polskiej nauce. Daje ono także asumpt do pogłębionych badań. Przed omówieniem zjawiska UBM wskazano na liczne problemy metodologiczne, na które natrafiono podczas prowadzenia badań.

Przedstawiono w nim szkicowo historię UBM, założenia ideologiczne obecne w utworach muzycznych najważniejszych zespołów od połowy lat 90. do dziś, zaprezentowano w sposób autorski trzy fale UBM, dokonano wstępnej systematyzacji treści, zamykając ją w działy tematyczne, akcentując stosowane zabiegi stylistyczne oraz terminologię.

Teksty UBM odnoszą się głównie do Biblii, zarówno Starego, jak i Nowego Testamentu, niemniej tekstowo UBM nie redukuje się do religijnych treści. Wyeksponowano jedenaście działów tematycznych, kilkadziesiąt środków wyrazu oraz zastosowane mechanizmy propagandowe. Głównym wnioskiem jest to, że w związ$\mathrm{ku} z$ deficytem w nauce ( $\mathrm{w}$ tym przypadku socjologii muzyki) problematyki chrześcijańskiego metalu niniejszy artykuł stanowi dobre wprowadzenie w zupełnie nieznane zagadnienie, co już w punkcie wyjścia stanowi znaczną wartość poznawczą.

KEYWORDS: black metal, unblack metal, satanism, Christianity, neopaganism, sociology of music, sociology of knowledge.

SŁowA KLUCzowe: black metal, unblack metal, satanizm, chrześcijaństwo, neopogaństwo, socjologia muzyki, socjologia wiedzy.

\section{WPROWADZENIE}

Unblack metal (UBM) to agresywny metal chrześcijański, który stanowi podgatunek black metalu (BM). Powstał on w połowie lat 90. XX w., stając się bezpośrednią odpowiedzią na rewolucję satanistyczną, jaka przetoczyła się przez kraje skandynawskie. Jest to także swoisty ruch społeczny, prowokacyjnie i programowo kontestujący antyreligijne, satanistyczne i neopogańskie ideologie obecne w muzyce metalowej, jednocześnie promujący chrześcijański światopogląd przy zachowaniu metod i technik muzycznych oraz scenicznych form przekazu, jaki charakteryzuje satanistyczny i neopogański black metal. 
W tym artykule zmierzę się z następującym wyzwaniem. Chciałbym, aby tekst był wstępną, ale rzetelną analizą eksploracyjną, bodźcem do dalszego wchodzenia w strefę mroku muzycznego UBM. W związku z licznymi wyzwaniami i trudnościami, jakie napotkałem w czasie konstruowania tej wypowiedzi, musiałem oprzeć się tymczasowo na badaniu eksploracyjnym. Uczyniłem tak z trzech zasadniczych powodów.

Po pierwsze, niniejszy artykuł jest pierwszą próbą zaprezentowania w polskiej socjologii chrześcijańskiego metalu w ogóle. Bez odniesień do historii, do podstawowych idei, specyficznych działań społecznych, bez prezentacji sylwetek niektórych istotnych zespołów i artystów trudno zrozumieć ten fenomen, a już na pewno nie należało zaczynać tej opowieści o UBM np. od skrupulatnego analizowania treści utworów tego gatunku. Brak wcześniejszego wprowadzenia Czytelniczek i Czytelników w specyfikę systemu kulturowego UBM, terenu zupełnie nieobecnego w dyskursie naukowym, mogłoby tworzyć nieporozumienia.

Po drugie, zespoły, które można przedstawić w pierwszym artykule odzwierciedlają $\mathrm{w}$ pewnym stopniu istotne zagadnienia, które charakteryzują świat chrześcijańskich metalowców. Dla mnie nie jest to terra incognita, znam twórczość wszystkich zespołów z tego gatunku (nie tylko z UBM, ale i BM), zarówno tych najbardziej znanych, jak i niszowych.

Po trzecie, założony rozmach precyzyjnego omówienia wszystkich utworów wylosowanych zespołów z płyt debiutanckich, środkowych i ostatnich sprawiłby, iż w sensie ilościowym wykroczyłoby to znacząco poza granicę jednego arkusza. Należało działać optymalnie, dlatego wybrałem drogę metodologicznego środka. Omówiłem szkicowo historię UBM, wiążąc ten fenomen z BM, zaproponowałem autorską prezentację trzech fal UBM, a po wcześniejszym przeczytaniu i wysłuchaniu kilkuset piosenek UBM dokonałem wstępnej syntezy działów tematycznych, stylistyki oraz terminologii. Próbowałem w tych działaniach zachować maksymalną jakość naukową, a jednocześnie przedstawić ciekawą narracyjnie opowieść o podziemnym metalu chrześcijańskim, jakże nieznanym w świecie naukowym. Styl mojej wypowiedzi nawiązuje do zaangażowanej narracji preferowanej przez Georga Simmla, a na obszarze współczesnej socjologii do stylu brytyjskiego socjologa muzyki Simona Fritha, autora niezwykłego i wciąż aktualnego studium z połowy lat 90 . XX w. pt. Sceniczne rytuały. O wartości muzyki popularnej (Frith, 2011). 
Jednocześnie nie zaniechałem przedstawienia podbudowy teoretyczno-metodologicznej mojej wypowiedzi. O problemach metodologicznych wspomnę szerzej w odrębnej części, tu na wstępie powiem słowo o teorii. Zjawisko UBM umieszczam w modelu zaproponowanym przez Marka Jezińskiego, autora terminu „audiosfera kultur grupowych” (AKG), który istnieje równolegle do audiosfery zinstytucjonalizowanej oraz niezinstytucjonalizowanej. Audiosferę kultur grupowych współtworzą zapisane i zaprogramowane w społecznej pamięci zbiorowej fundamentalne faktory generujące tożsamości społeczne oraz indywidualne, a także doświadczenia zbiorowe sui generis poszczególnych pokoleń. Ten termin jest przydatny dla mojej analizy, gdyż AKG można odnieść do tradycyjnych zbiorowości, jak grupa etniczna, narodowa, subkultura, ale także, co znamienne, do społeczności wirtualnych (Jeziński, 2017, s. 23). Pomiędzy powyższymi kategoriami lokują się utwory, które stanowią istotne elementy kształtowania tożsamości grup osób. Często występują jako symbole określonej epoki - związane są z wydarzeniami historycznymi, ale także przeżyciami, emocjami, jakich doświadcza dana zbiorowość.

Tę kategorię audiosfery nazwać można audiosferą kultur grupowych, a stanowią ją przede wszystkim utwory symbole, które zakodowały się w zbiorowej pamięci na zasadzie nośnika pamięci kulturowej - pewnych nie tyle wartości (przypisanych wszak często utworom audiosfery zinstytucjonalizowanej, choć istotnych także dla audiosfery omawianej w tym punkcie), ile skojarzeń czy przeżyć dotyczących jakiegoś istotnego okresu w życiu większej grupy osób, podzielającej kolektywnie pewne doświadczenie życiowe. [...] Do tej grupy należą zatem największe przeboje jakiegoś okresu - symbole określonego, silnie nacechowanego emocjonalnie momentu historycznego. Opisywana kategoria utworów ma z założenia charakter elitarny i egalitarny, integracyjny i ekskluzywny - jest pewną deklaracją uczestnictwa w określonym wymiarze kultury, związanym z doświadczeniami grupowymi. Użycie tych właśnie utworów dookreśla grupowe doświadczenia, a sama audiosfera pełni także funkcje integracyjne (tamże, 2017, s. 23-24). 


\section{METODY BADAWCZE}

Zanim przejdę do omówienia fenomenu społeczno-kulturowego, jakim jest UBM, zacznę od czterech zasadniczych uwag metodologicznych ukazujących problemy, z jakimi przyszło mi się zmierzyć, opracowując materiał do tego artykułu, a które to problemy będę się starał w miarę możliwości i rozwoju badań nad interesującym mnie zjawiskiem (z punktu widzenia socjologii wiedzy oraz socjologii muzyki) rozbijać i minimalizować w kolejnych publikacjach.

Bohaterami mojego tekstu uczyniłem reprezentantów wszystkich trzech fal UBM. I tu pierwsza uwaga metodologiczna, która dotyczy autorskiej umowy określającej ramy czasowe dla powstania poszczególnych fal UBM. Jest to moja propozycja i konwencja, dlatego nie należy traktować jej jako aksjomatu. Umieszczenie konkretnych zespołów, które przynależą do pierwszej, drugiej czy trzeciej fali uzależniam od historycznej chronologii, przede wszystkim od daty powstania zespołu/projektu, a nie od daty wydania debiutanckiej płyty. Muzycy zespołów, o których piszę, nie działają od „dziš” czy „wczoraj” na scenie metalowej, lecz przeciwnie, ich projekty w ramach UBM są kulturowymi bytami stanowiącymi bardzo konkretną odpowiedź na historyczne wydarzenia związane z satanistyczną rebelią w Norwegii, jaka się rozpętała i przetoczyła przez całą Skandynawię w połowie lat 90. XX w. Niektóre zespoły pierwszej fali debiutowały późno.

Druga uwaga metodologiczna dotyczy rozumienia przeze mnie UBM. Unblack metal rozumiem szeroko, ale znów nie za szeroko. Szeroko, ponieważ nie „ortodoksyjnie”. Wymienione z nazw zespoły z obu Ameryk, Australii, Europy wskazują, że nie można redukować zjawiska UBM do krajów skandynawskich. Takie założenie moim zdaniem nie wyczerpywałoby fenomenu UBM, choć pewnie uzasadniałoby metodologiczny porządek ramowy danej wypowiedzi. Nie traktuję ponadto twórców tego podgatunku na zasadzie odwróconego zwierciadła w konfrontowaniu ich ze sceną blackmetalową (zasada dialektyki negatywnej). Wówczas mocno ograniczyłbym problematykę i filozofię UBM. Powstałaby sztuczna synteza, która zwracałaby uwagę wyłącznie na: a) kraj pochodzenia (region skandynawski, przede wszystkim Norwegię), b) treści utworów (antysatanistyczna, antypogańska retoryka ideologiczna, wojownicze tony skierowane przeciwko wrogom 
Boga, których należy zwalczać, a broniące i wysławiające Jezusa i Boga), c) atrybuty sceniczne: czarny skórzany strój wojownika, uzbrojenie: kolczat$\mathrm{ki}$, miecze, kolczugi, topory, pochodnie, malowanie ciała (ang. corpse paint), d) sposoby wypowiedzi muzycznej: charakterystyczny skrzek wokalny, szybkie blasty i bity perkusyjne, ciężkie i rytmiczne akordy gitarowe, mroczne partie syntezatorów, e) formę graficzną, ilustracje, cover arty: smutne, depresyjne ilustracje, czarno-białe okładki albumów.

To stereotyp, który pragnę obalić. Artyści UBM: a) wykraczają poza Skandynawię $^{1}$, b) piszą nie tylko teksty teologiczne, opierające się na dychotomii Bóg-Szatan, ale również polityczne, liryczne, filozoficzne (zob. tab. 1), c) nie muszą malować twarzy oraz zakładać skórzanych kurtek ani dzierżyć w dłoniach toporów, d) korzystają z synkretycznych form muzycznych, śpiewają czystym głosem (ang. clean vocal), grają wolne, wręcz balladyczne utwory, e) decydują się często na kolorowe okładki, pozytywne i estetycznie „ładne”.

Jednocześnie UBM nie traktuję za szeroko, nie włączam do niego ani power metalu, ani heavy metalu, grunge’u, trasu, ani tym bardziej chrześcijańskiego hard rocka. Chcę zaprezentować muzyków, którzy grają bardzo ostrą muzykę, na pograniczu mocniejszych melodyjnie gatunków metalu, jak death metal (techniczny, melodyjny, gotycki, symfoniczny, atmosferyczny etc.), black, blackened death, a którzy są samoświadomymi chrześcijanami tworzącymi już od połowy lat 90 . XX w. swoje projekty, będące bezpośrednią reakcją na drugą falę black metalu, czyli na powstające od wczesnych lat 90 . projekty satanistyczne czy szerzej antychrześcijańskie/neopogańskie, takie jak Behemoth (wcześniej Baphomet), Burzum, Dark Throne, Emperor, Mayhem, Satyricon (będące drugą falą BM)².

Trzecia uwaga metodologiczna dotyczy źródeł․ Sądzę, że wszyscy naukowcy, którzy chcą pisać o metalu ${ }^{4}$ (nie tylko chrześcijańskim), borykają się z podobnymi problemami metodologicznymi. Są pionierami, forpocztą, uczonymi, którzy od niedawna badają naukowo scenę metalową $a^{5}$. Nie inaczej jest z moim artykułem. Materiały książkowe są niewystarczające dla zagadnienia UBM. Bez oparcia się na zasobach internetowych nie miałbym możliwości stworzenia tej opowieści. Nawet popularno-naukowe publikacje o metalu omijają szerokim łukiem lub po prostu przemilczają fenomen UBM, począwszy od znanej pracy Iana Christe - Sound of the Beast (Christe, 2010). 
Dlatego musiałem poszukiwać poważnych źródeł, korzystając głównie ze sprawdzonych i profesjonalnych zasobów internetowych, a zatem owoców Rewolucji 4.0. Dzięki sieci można bez przeszkód dotrzeć do najważniejszych utworów i albumów zespołów, których próżno szukać w sieciach Empik i na Allegro (w odróżnieniu od zespołów sceny blackmetalowej, która ma godną reprezentację w sklepach nastawionych na masowego odbiorcę). Głównym wsparciem były dla mnie następujące źródła: serwis Spotify, film dokumentalny z 2008 r. o chrześcijańskim metalu Light in the Darkness 'Nemesis Divina' autorstwa Stefana Rydeheda i Davida Nilssona oraz Encyclopaedia Metallum (EM). Na Spotify odsłuchiwałem utwory wszystkich interesujących mnie zespołów, na filmie udostępnionym w serwisie YouTube mogłem posłuchać wypowiedzi muzyków chrześcijańskich o ich motywacjach, stylu życia, światopoglądzie, o zagrożeniach ze strony satanistów i neopogan, natomiast Encyclopaedia Metallum jest zasobem skondensowanej wiedzy, którą trzeba i należy uwzględniać przy badaniach jakościowych nad fenomenem społeczno-kulturowym metalu, będącym jednocześnie dowodem na współistnienie - obok równoległego i tradycyjnego społeczeństwa informacyjnego, korzystając z koncepcji Małgorzaty Such-Pyrgiel - w równej mierze społeczeństwa cyfrowego (Such-Pyrgiel, 2019, s. 295). To nie tylko skondensowana wiedza o metalu, jak wspomniałem, ale także miejsce spotkań i wymiany myśli w wirtualnej rzeczywistości fanów muzyki mogących dyskutować na forach, pisać recenzje, nawiązywać relacje, przekazywać doświadczenia oraz wiedzę. Na stronie EM aktywność przejawia 843291 członków, a w sumie zarejestrowanych jest ponad milion osób (1 216 218). Gdy przygotowywałem ten artykuł, każdy ze wspomnianych zespołów, także te wymienione tylko $\mathrm{z}$ nazwy, został przeze mnie poznany bardzo precyzyjnie, to znaczy poświęciłem na słuchanie poszczególnych produkcji kilkadziesiąt godzin, zapoznając się dwukrotnie w sposób uważny z całą dyskografią. Dodatkowo dotarłem do wszystkich tekstów piosenek i na ich bazie mogłem tworzyć pierwsze robocze i hipotetyczne uogólnienia i syntezy, poznałem także bliżej historię muzyków i dyskografię interesujących mnie zespołów.

Uwaga metodologiczna numer cztery. Artykuł jest owocem badania bardziej eksploracyjnego niż wyjaśniającego. Na badanie wyjaśniające jest 
jeszcze za wcześnie z uwagi na kilka deficytów. To zaledwie i aż zaczyn, materiał ważny, ale niereprezentatywny. Dlaczego? Odpowiedź metodologa, którym także jestem, musi być poważna i adekwatna wobec wątpliwości sceptyków metodologicznych.

W artykule chciałem początkowo zająć się szeroką prezentacją treści ideologicznych utworów UBM. W międzyczasie artykuł rozrósł się do trzech arkuszy wydawniczych, które wciąż nie wyczerpywały zagadnienia, a zatem dalsze postępowanie nie wydałoby artykułu, ale monografię. Nie „czekając na polskiego Godota”, sam się nim niejako stałem, ponieważ chciałem wprowadzić już teraz Czytelniczki i Czytelników w tę Boską ciemność (nawiązuję tu do tytułu albumu szwedzkiego zespołu Crimson Moonlight Divine Darkness). Musiałem zatem, choć szkicowo, zaprezentować historię UBM, toczącą się równolegle do rozwoju black metalu, będącego bezpośrednim asumptem do wyłonienia się tego subpodgatunku (z podgatunku ${ }^{7}$ ). Stąd musiałem poniechać pierwotnego zamysłu i znacząco ograniczyć założony rozmach metodologiczny, teoretyczny, empiryczny.

I na koniec tego podrozdziału chciałbym zaprezentować najważniejsze źródło wiedzy o metalu, którym jest sieciowa, wciąż rozbudowywana Encyklopedia Metalu (EM), stworzona w Montrealu w 2002 r. przez dwóch Kanadyjczyków o pseudonimach Morrigan i HellBlazer. Aktualnie encyklopedia zawiera opracowania 148195 zespołów metalowych, spośród nich 82537 są aktywne, 3378 zawiesiło swą działalność, 46079 rozpadło się, 6166 zmieniło nazwę, 10012 ma nieznany status. Ponadto do bazy Encyklopedii... wprowadzono 39344 wydawnictw, z których 17642 jest aktywnych, 12383 zamkniętych, 336 zmieniło nazwy, 8802 ma nieznany status swej działalności. Dodano również 773937 muzyków, spośród których ponad pół miliona jest nadal aktywnych artystycznie (tj. 637 018), 136919 porzuciło karierę muzyczną w metalu, 6257 osób nie żyje, 53573 jest kobietami ${ }^{8}$, a 712275 mężczyznami. Wreszcie do bazy wprowadzono pół miliona albumów (437 995) i 3 mln piosenek (3 066 561) wraz z tekstami (EM, 2021). Dostęp do bazy jest darmowy, a dane codziennie aktualizowane. Statystyki mogą przekonywać, że opracowany operat i baza wyjściowa dla badań metalu jest rzetelna i trafna zarazem. 


\section{BOHATEROWIE SPEKTAKLU: HORDE I TRZY FALE UBM} Horde

Momentem zapowiadającym pojawienie się UBM jest rok 1990, gdy w Melbourne powstaje Mortification, australijski chrześcijański zespół trashmetalowy. Jego perkusista, Jayson Sherlock cztery lata później (1994) wydaje w słynnym wydawnictwie Nuclear Blast (NB) kontrowersyjny, nawet jak na realia BM czy jeszcze szerzej - metalu, album Hellig Usvart, który staje się dziełem przełomowym i do dziś stanowi kultowy materiał dla metalowców. Jednoosobowy projekt Sherlocka występującego pod pseudonimem Anonymous wywołuje szok w Norwegii, w której akt ten odczytano jako prowokację. Nie bez przyczyny. Sherlock wystąpił pod pseudonimem, który nawiązywał do znanej postaci ze świata satanistycznego podziemia, Norwega $\varnothing_{y}$

steina Aarsetha (1968-1993), znanego jako Euronymous, założyciela i lidera wczesnej sceny blackowej w Norwegii, jeśli nie w całej Skandynawii. Aarseth już wówczas nie żył. W 1993 r. zadźgał go lider z konkurencyjnego projektu Burzum, Varg Vikernes, znany jako Count Grishnackh (Christe, 2010). Żyli natomiast wyznawcy satanizmu, Euronymousa i podziemia blackowego. Zarówno Jayson Sherlock, jak i pierwszy wydawca krążka otrzymywali pogróżki. Zwłaszcza na wydawnictwo NB wywierana była presja, aby zrezygnowano z kontraktu z Horde. Nuclear Blast pozostało nieugięte (Rydehed, Nilsson, 2008). Na płycie Sherlock przejął wszystkie formy, na jakie stać było ówczesny black metal, z tą jedną różnicą, że przesłanie blackowe zostaje odwrócone, i to dosłownie - Horde odwraca odwrócony krzyż. Ustawia w centrum narracji Boga, Jezusa jako Pana i Zbawiciela. W dwunastu utworach przez 40 minut i trzydzieści sekund zachęca do porzucenia diabła. Poprzestanę na tłumaczeniu tytułów utworów, które dadzą pewne wyobrażenie o ideologii Sherlocka zawartej w jego piosenkach: 1) Bicie dzwonu kościelnego wśród zamarzniętych wichrów nordyckich; 2) Bluźniercza obrzydliwość satanistycznego pentagramu; 3) Ukaż się, o szkarłatny księżycu; 4) Twoja godzina nadeszła (podmiot liryczny zwraca się w utworze wprost do Lucyfera); 5) Uwolnij i okryj szatą dziewiczą ofiarę (piosenka o asyście aniołów ku wolności uratowanej od złożenia w ofierze diabłu dziewicy); 6) Pij Jego krew wprost $z$ kielicha (zachęta do picia krwi Zbawiciela dla uratowania życia); 
7) Uciszyć bluźniercze pieśni; 8) Odwróć odwrócony krzyż; 9) Opustoszaly grób skąpany w świetle księżyca (poetycki utwór o zmartwychwstaniu ciała); 10) Zmiażdż zakrwawione rogi kozła (wojowniczy i agresywny utwór o deptaniu i miażdżeniu w proch bożków i symboli satanistycznych); 11) Słaby, ostabiony, umierający antychryst; 12) Dzień totalnego holokaustu i Armagedonu (EM, 2017).

Podsumowując: ostatecznie, głosi Horde, to Bóg jest zwycięzcą i pogromcą zła, szatana, demonów i jego ludzkich legionów. Trzeba przyznać, że Horde to mocny i precyzyjny cios zadany black metalowi, gdyż, oprócz semantycznych odwołań, ideologiczny przekaz jest właściwie spójny i logiczny: wybieram Boga judeochrześcijańskiego, odrzucam szatana, który ostatecznie zostanie wrzucony w najgłębsze otchłanie piekielne. Teksty są poetyckie, ale mroczne, zawierające elementy przemocowe, zachęcające do agresywnych i destrukcyjnych działań. Atmosfera liryków jest grobowa, mroczna, sceneria także, słyszymy bicie dzwonów, wichry, skrzypienie gałęzi drzew na cmentarzach, bluźniercze pieśni, widzimy puste groby, krew wylewającą się ze świętego kielicha, składaną diabłu w ofierze dziewicę ratowaną przez anioły, zakrwawione rogi kozła, umierającego antychrysta, obserwujemy finalną bitwę, zwaną Armagedonem, i ludobójstwa na końcu czasu, gdy dopełnią się dni. Występują tu także klasyczne obrazy apokaliptyczne, krwawe słońce, szkarłatny księżyc. Ponadto kompozycje Horde do dziś pozostają na wysokim poziomie artystycznym i z powodzeniem zarówno ówcześnie, jak i dziś konkurowały i konkurują z klasycznymi albumami BM. W mojej ocenie estetycznej, pozostając oczywiście w kanonie gatunku, są nawet lepsze.

\section{Trzy fale UBM}

Oprócz Horde do pierwszej fali należy Admonish, norweski Antestor grający nieprzerwanie od 1989 r., Extol, Crimson Moonlight. Do pierwszej fali UBM należą także zespoły z innego kręgu kulturowego, polski Elgibbor oraz np. brazylijski Cerimonial Sacred (powstały w 1998). Inne zespoły pierwszego nurtu to Extol (1993), który zawiesił działalność, niemieckie Sacrificium (1993), Drottnar (1996), szwedzki Pantokrator (1996), norweski Frosthardr (1997), norweski Vardøger (1996-2018) ukraiński Holy Blood (1999) oraz Azmaveth (1999) z Puerto Rico czy nieistniejące norweskie Vaakevandring (1999-2007). 
Nowe Milenium traktuję jako cezurę dla powstania drugiej fali. Na rynku muzycznym pojawiły się wówczas wydawnictwa holenderskiego Slechtvalk (powstałe w 2000 r.), północnoamerykańskiego Frost Like Ashes (2001), szwedzkiego Shadows of Paragon (2001), brazylijskiego Divine Symphony (2001), armeńskiego Blood Covenant (2001), fińskiego Renascent (2003), meksykańskiego Hortor (2004), angielskiego Wintersoul (2006).

Do trzeciej fali zaliczam późniejsze i powstające także dziś projekty chrześcijańskiego agresywnego metalu: mam na myśli norweskie Grave Declaration (2006), niemiecki Eternal Emperor (2007), Vials of Wrath (2011) z USA, amerykańsko-fiński Antivenom (2012), szwedzkie Skald in Veum (2013) oraz Melech (2017) .

\section{ANALIZA ZAWARTOŚCI TREŚCI UTWORÓW UBM: DZIAEY TEMATYCZNE, STYLISTYKA, TERMINOLOGIA ${ }^{10}$}

W tej części artykułu chciałem zająć się przedwstępną syntezą twórczości muzyków reprezentujących agresywny metal chrześcijański, którą podzieliłem na działy, stylistykę, terminologię. Ponieważ nadal podążam samotnie w naukowym oglądzie tego fenomenu, sądzę, że perspektywa ta będzie z czasem weryfikowana, a poszczególne propozycje modyfikowane, gdy użyję systematycznych metod badawczych. Zaproponowane działy (zob. tab. 1) zazębiają się i nachodzą na siebie, nie można ich traktować odrębnie, pozostają raczej typami idealnymi.

Po lekturze kilkuset utworów większości zespołów trzech fal UBM mogę bezpiecznie założyć, że punktem wyjściowym w UBM jest to, że: a) Bóg istnieje, b) Bóg ze Starego i Nowego Testamentu jest tym samym Bogiem, c) człowiek jest grzesznikiem, którego d) od śmierci i potępienia wiecznego uwolniła ofiara cierpienia i śmierci na krzyżu Jezusa z Nazaretu, e) Jezus Chrystus zmartwychwstał, f) w tekstach wrogiem Boga i człowieka czyni się przede wszystkim szatana i jego sługi, demony i ludzi, g) człowiek po śmierci idzie pod Sąd, h) po którym Bóg decyduje, czy resztę wieczności spędzi on w niebie, czy w piekle, i) pod koniec historii Jezus powróci na Ziemię, wreszcie j) na końcu świata odbędzie się Sąd Ostateczny, poprzedzony Armagedonem. 
Tabela 1.

Działy tematyczne treści utworów chrześcijańskiego metalu

\begin{tabular}{|c|l|}
\hline Dział & \multicolumn{1}{|c|}{ Tematyka, wątki, problematyka } \\
\hline Filozoficzny & $\begin{array}{l}\text { Zapytania o sens życia, prawdę, sens stworzenia świata, } \\
\text { o związki i relacje między ludźmi }\end{array}$ \\
\hline Egzystencjalny & $\begin{array}{l}\text { Rozważania na temat losu człowieka za życia, losu ludzi } \\
\text { po śmierci, zajmowanie się problemem samobójstwa, aborcji }\end{array}$ \\
\hline Psychologiczny & $\begin{array}{l}\text { Emocje, jakie tu przeważają, to smutek, depresja, } \\
\text { ale zdarzają się mocniejsze stany, jak nienawiść, gniew } \\
\text { (święty i usprawiedliwiony), schadenfreude ze zgubnego } \\
\text { losu niewiernych i bezbożników, stosowanie szantażu emo- } \\
\text { cjonalnego, radość, nadzieja, euforia }\end{array}$ \\
\hline $\begin{array}{c}\text { Pedagogiczny (poprzez } \\
\text { apologetykę) }\end{array}$ & $\begin{array}{l}\text { Nauczanie, misyjność, straszenie sądem Bożym, karą, ze- } \\
\text { mstą }\end{array}$ \\
\hline Etyczny & $\begin{array}{l}\text { Dobro, zło, wybór, predestynacja, konieczność, przypadek, } \\
\text { wolność }\end{array}$ \\
\hline Poetycki & Opisy przyrody, stanu duszy, epickie relacje z batalii \\
\hline Religijny & $\begin{array}{l}\text { Dogmatyka zgodna zazwyczaj z doktryną chrześcijańską, } \\
\text { głównie protestancką, koncepcje religijne są zależne od de- } \\
\text { nominacji chrześcijańskiej muzyków }\end{array}$ \\
\hline Polityczny & $\begin{array}{l}\text { Problemy dotyczące wielkiej polityki narodów i państw, pro- } \\
\text { wadzącej do Armagedonu i końca świata }\end{array}$ \\
\hline Ekologiczny & Problematyka niszczenia planety Ziemi przez ludzi \\
\hline Historyczny & Narracja o dziejach świata, narodów, Kościoła \\
\hline Fantyczny & $\begin{array}{l}\text { Opowieści o fikcyjnych krainach, które mają stanowić meta- } \\
\text { forestwa Bożego }\end{array}$ \\
\hline & \\
\hline
\end{tabular}

Źródło: opracowanie własne na podstawie danych zawartych w Encyklopedii Metalu.

Z jednej strony w większości przypadków są to teksty religijne, opierające się na założeniu o boskim bohaterstwie Jezusa, który zginął w męczarniach, ale finalnie zwyciężył grzech, szatana, śmierć, a ponieważ nie wszyscy o tym wiedzą lub jeśli wiedzą, to odrzucają zbawienie, dlatego trzeba im przypominać o biblijnych wydarzeniach i w sposób zdecydowany ostrzec przed złą 
drogą, którą kroczą, kończy się ona bowiem w piekle. Teksty ukazują moc ofiary krzyża, a krew zabitego Boga-człowieka oczyszcza wszystko.

Z drugiej strony - występujące ostrzeżenia, groźby wprowadzane są na tory batalistyczne i wojownicze. Teksty zachęcają do akcji, do działania, agresywnego i destrukcyjnego, zamykając się w hasłach: „Niszcz! Walcz! Depcz!”, kierując się w stronę bezbożnych symboli, bożków pogańskich, idoli, znaków szatańskich, łbów kozłów, pentagramów, rogów.

Autorzy, wyrażając swoje poglądy, które pogrupowałem w powyższe działy tematyczne, posługują się licznymi środkami stylistycznymi, charakterystyczną terminologią, bazując na ostrych dychotomiach. Zastosowane środki wyrazu to: alegorie, amplifikacje, anafory, animizacje, antropomorfizacja, apostrofy, archaizmy, dialektyzacje, enumeracje, epitety, hiperbole, inwokacje, kolokwializmy, kontrasty, metafory, metonimie, oksymorony, onomatopeje, parafrazy, parentezy, pleonazmy, powtórzenia, pytania retoryczne, retrospekcje, rym, wykrzyknienia.

Wśród standardowych wyjściowych i bezproblematycznie założonych zabiegów stylistycznych dostrzec możemy dość wyraźnie radykalne dychotomie i mowę dualizującą: dobro-zło, piękno-brzydota, wolność-niewola, życieśmierć, zmartwychwstanie-potępienie, niebo-piekło, grzech-oczyszczenie, Bóg-szatan, zbawiony-potępiony, wolny-zniewolony, światło-ciemność.

Innym zagadnieniem jest stosowanie w UBM określonej terminologii. Częstymi terminami są: śmierć, życie, krew, szatan, Bóg, grzech, Jezus, król, królowie, niewolnicy, Armagedon, apokalipsa, sny, ciemność, czerń, cienie, wieczność, potępienie, niebo, raj, piekło, łzy, smutek, trony, wilki, aniołowie, węże, klątwy, bluźnierstwa, tyrani, bożki, pogaństwo, demony, lasy, morza, góry, rzeki. W opisach przyrody jedne siły i zjawiska natury mają pozytywne konotacje, a inne negatywne - słońce to dobro, księżyc - zło, lasy są raczej złe, dzień - dobry, a noc - zła, zwierzęta dobre to owce, gołębie, złe - to kozły, węże, wilki, sowy.

W obszerniejszej monografii będę mógł ukazać szczegółowo tę problematykę i wskazać, które działy, środki stylistyczne i terminologia przeważają i które można jeszcze dodać, zweryfikować. W tym miejscu zakładam hipotetycznie, że przede wszystkim: działy dotyczą tematów religijnych, teologicznych, apologetycznych i moralizatorskich, przeważa terminologia ciemności, 
zła, szatana, piekła, zastosowane środki stylistyczne będą jeszcze bogatsze, a żeby je uwypuklić, będę przywoływać konkretne przykłady piosenek, w których zostały wykorzystane.

\section{Podsumowanie}

Unblack metal to zjawisko całkowicie niezauważone w świecie socjologicznym, to ziemia nieznana, dotąd nieeksplorowana. Chciałbym zainaugurować wypełnianie tej luki, dlatego niniejszy artykuł jest pierwszym krokiem do licznych działań badawczych, mających na celu gruntowne przerobienie i zrozumienie tego fenomenu. Jako znawca sceny zarówno BM, jak i UBM uważałem, że najpierw należy przedstawić bohaterów spektaklu, zarysować, choćby szkicowo, historię, zaprezentować najważniejsze zespoły trzech fal UBM, zaproponować wstępną syntezę działów tematycznych występujących w UBM, stosowaną tu stylistykę oraz terminologię. Tym samym sygnalizuję, że zajmowanie się UBM nie jest zajęciem estetycznym, odnoszącym się do socjografii historii muzyki, ale badanie otwiera wiele możliwości, aby traktować ten fenomen z punktu widzenia socjologicznego ${ }^{11}$. Audiosfera kultur grupowych konsolidowana jest przez muzykę, jej moc społeczna jest zatem potężna i bardzo ważna dla scalania labilnej wspólnoty, zarówno pod względem estetycznym, jak i dlatego że skupia ją wokół preferowanych wartości (Cyrek, 2020, s. 158).

Będąc dopiero po fazie wstępnej gromadzenia materiałów do badań, po lekturze kilkuset tekstów piosenek zespołów z pierwszej, drugiej i trzeciej fali, mogę skonstatować we wstępnych hipotezach, które poprowadzą mnie do pogłębionych badań, że teksty UBM odnoszą się głównie do Biblii, zarówno Starego, jak i Nowego Testamentu. Mam wrażenie, które chciałbym jeszcze uszczegółowić precyzyjną analizą, że doktryna bazuje głównie na Listach św. Pawła, ale obrazy, z których czerpane są inspiracje, to głównie Stary Testament i Objawienie św. Jana. Zdarza się korzystać autorom $\mathrm{z}$ opisów wydarzeń z Ogrójca i drogi krzyżowej obecnych w Ewangeliach, niemniej tekstowo UBM nie redukuje się do treści religijnych. Wyeksponowałem jedenaście działów tematycznych, kilkadziesiąt środków wyrazu oraz zastosowane mechanizmy propagandowe. 
Losy ludzkie są skomplikowane i nieprzewidywalne. Scena UBM od połowy lat 90. trwa, pomimo jej całkowitej niszowości i, trzeba to przyznać, swoistej irracjonalności. Tę społeczno-kulturową aberrację, życie na granicach różnych kulturowych światów należy potraktować jednocześnie poważnie i z uwagą, gdyż jej socjologiczno-kulturowe wskaźniki mówią nam wiele o mało znanych sferach i warstwach podsystemu kulturowego, jakim jest chrześcijański metal, jego twórcy, jego odbiorcy, jego wrogowie, więcej nawet, mówi nam wiele o socjologicznej powierzchni, jej jawnych i półjawnych systemach kulturowych, pod którymi tętni dynamicznie niezauważalne niemal podziemie licznych subkultur, wobec których socjolog wiedzy nie może pozostawać obojętny. Gusta muzyczne, wiemy to naukowo co najmniej od Dystynkcji... Pierre’a Bourdieu (Bourdieu, 2005), kształtowane są kulturowo, w związku z czym badanie gatunków muzycznych staje się oceanicznie fascynującą głębią wartości, norm, stratyfikacji, ideologii i usytuowań w kulturze badanych.

Za pomocą narzędzi socjologii muzyki, na podstawie refleksji socjologii wiedzy oraz konstruktywizmu społecznego można odważyć się na wyruszenie na tę fascynującą wyprawę, i chociaż tematyka UBM jest zagadnieniem niszowym, to w polskiej socjologii pionierów i pionierek podejmujących się badań w ramach socjologii muzyki nie brakuje ${ }^{12}$. Ich odkrycia i wynalazki będą przydatne do moich badań. Dlatego mam nadzieję, że w najbliższej przyszłości będę mógł w badaniach tej sceny muzycznej zweryfikować zaproponowane tu wstępne hipotezy, tezy, syntezy i wnioski. Ponieważ badanie jest już przygotowane metodologicznie, będę mógł się oprzeć na reprezentatywnych badaniach, przeprowadzonych zarówno wśród przedstawicieli tego gatunku, jak i twórców i fanów oraz na poważnej analizie zawartości treści, wykorzystującej programy CAQDAS. Moim głównym wnioskiem z prowadzonej dotychczas analizy jest to, że w związku z deficytem $\mathrm{w}$ nauce, w tym przypadku socjologii muzyki, problematyki chrześcijańskiego metalu niniejszy artykuł stanowi dobre wprowadzenie w zupełnie nieznane zagadnienie, co już w punkcie wyjścia stanowi znaczną wartość poznawczą. 


\section{Bibliografia}

Bourdieu, P. (2005). Dystynkcja. Społeczna krytyka władzy sadzenia, Warszawa: Wydawnictwo Naukowe Scholar. ISBN 8373830901.

Cebula, M., Pilch, Sz. (2020). Społeczne zróżnicowanie gustu muzycznego, „Studia Socjologiczne", nr 1(236), s. 73-104. ISSN 0039-3371.

Choczyński, M., Rozalska, A., Drzewek, K. (2018). Socjologia muzyki w Polsce: pęknięcia i kontynuacje, Warszawa: Warszawskie Wydawnictwo Socjologiczne. ISBN 9788394701284.

Christe, I. (2010). The Sound of the Beast. The Complete Headbanging History of Heavy Metal, New York: HarperCollins, e-book. ISBN 9780380811274.

Cyrek, B. (2020). Muzyk w praktyce donacji internetowych - na przykładzie serwisu YouTube. W: E. Nidecka, J. Wąsacz-Krztoń (red.), Muzyk jako przedmiot recepcji, refleksji pedagogicznej i badań interdyscyplinarnych, t. 2. Rzeszów: Wydawnictwo Uniwersytetu Rzeszowskiego, s. 154-162. ISBN 9788379967797.

Domański, H. i in. (2020). The Homology of Musical Tastes in Poland, „Studia Socjologiczne", nr 4(239), s. 183-211. ISSN 0039-3371.

Frith, S. (2011). Sceniczne rytuały. O wartości muzyki popularnej, Kraków: Wydawnictwo Uniwersytetu Jagiellońskiego. ISBN 9788323331698.

Jabłońska, B. (2014). Socjologia muzyki, Warszawa: Wydawnictwo Naukowe Scholar. ISBN 9788373837157.

Jabłońska, B. (2018). O społecznym charakterze muzyki. Szkic socjologiczny, „Pogranicze. Studia Społeczne”, nr 34, s. 113-128. ISSN 1230-2392.

Jeziński, M. (2017). Muzyka popularna jako forma pamięci kulturowej, „Kultura Współczesna”, nr 3(96), s. 14-25. ISSN 1230-4808.

KeeperOftheFlame (2002). Horde. W: Encyclopaedia Metallum, https://www.metal-archives.com/bands/Horde/3387 (dostęp: 28.05.2021).

Kierlan, J., Rex, J.W. (2018). Islamic Religion and Death Metal Music in Indonesia, „Journal of Popular Music Studies”, nr 30(3), s. 129-152. ISSN 1524-2226.

Korczyński, T.M. (2019). Kiedy dom zaczyna płonąć. Swój, obcy, wróg w Trzeciej Rzeszy - perspektywa konstruktywistycznej socjologii wiedzy, Gdańsk: Wydawnictwo Naukowe Katedra. ISBN 9788366107236.

Lutostański, M.J. (2015). Brzydkie słowa, brudny dźwięk. Muzyka jako przekaz ksztattujący styl życia subkultur młodzieżowych, Warszawa: Wydawnictwo Naukowe Scholar/SWPS. ISBN 9788373836969. 
Moberg, M. (2009). Faster for the Master. Exploring Issues of Religious Expression and Alternative Christian Identity within the Finnish Christian Metal Music Scene, Åbo: Åbo Akademis Förlag/Åbo Akademi University Press. ISBN 9789517654920.

Moberg, M. (2010). Turn or Burn? The Peculiar Case of Christian Metal Music. W: N. Scott, I. Von Helden (red.), The Metal Void. First Gatherings, Oxford: Inter-Disciplinary Press, s. 367-380. ISBN 9781904710875.

Moberg, M. (2012). The 'double controversy' of Christian metal, „Popular Music History", nr 6(1), s. 85-99. ISSN 1740-7133.

Otterbeck, J., Mattsson, D., Pastene, O. (2018). 'I am Satan!' black metal, Islam and Blasphemy in Turkey and Saudi Arabia, „Contemporary Islam”, nr 12, s. 267-286. ISSN 1872-0226.

Rydehed, S., Nilsson, D. Light in Darkness 'Nemesis Divina' - Christian Black Metal, https://www.youtube.com/watch?v=qTT79KjvRnQ\&t=1630s (dostęp: 28.05.2021).

Sokołowski, J. i in. (2019). A Comprehensive Study of the Polish Music Market, Warszawa: Narodowe Centrum Kultury.

Such-Pyrgiel, M. (2018). The Socio-Demographic Changes in Contemporary Polish Society - Selected Issues, „Politické vedy”, nr 21(4), s. 162-177. ISSN 1335-2741.

Such-Pyrgiel, M. (2019). Człowiek $w$ dobie cyfrowej transformacji. Studium socjologiczne, Toruń: Wydawnictwo Adam Marszałek. ISBN 9788366220966.

Stats. w: Encyklopaedia Metallum, https://www.metal-archives.com/stats (dostęp: 27.05.2021).

Szarecki, A. (2019). The Making of Polish Hip-Hop: Music, Nationality, and the Limits of Hegemony. W: P. Gałuszka (red.), Made in Poland: Studies in Popular Music, London-New York: Routledge, s. 155-164. ISBN 9781351119207.

Wyrzykowska, K.M. (2017). Muzyka, młodzież i styl życia. O uczestnictwie w kulturze muzycznej warszawskiej młodzieży, Warszawa: Warszawskie Wydawnictwo Socjologiczne. ISBN 9788394701246.

\section{Endnotes}

${ }^{1)}$ Kultowym do dziś projektem, który oficjalnie zainaugurował ruch UBM w połowie lat 90. XX w., był australijski zespół Horde. Myślę, że to wystarczający argument za poszerzeniem pola badawczego o różne kraje, nie tylko skandynawskie.

2) Do pierwszej fali BM, który w latach 80 . wykształcił się z trash metalu, można zaliczyć Bathory, Celtic Hellhammer, Frost, Venom. 
3) O black metalu i death metalu w nauce napisano wiele artykułów. Kłopot polega na tym, że niewiele miejsca $\mathrm{w}$ nich poświęcono na przybliżenie sylwetki chrześcijańskiego podgatunku, jakim jest unblack metal. Chwalebnym wyjątkiem jest książka oraz artykuły fińskiego socjologa prof. Marcusa Moberga z Åbo Akademi University w Turku. Moberg należy aktualnie do głównych zainteresowanych tym fenomenem (zob. Moberg, 2009, s. 320; Moberg, 2010, s. 367-380). Nadal jednak publikacji o UBM, także zagranicznych, jest niewiele.

4) W zasobach Web of Science znalazłem nie mniej fascynujące artykuły o sytuacji death metalu w największym państwie muzułmańskim, Indonezji, oraz black metalu w Turcji, a także w Arabii Saudyjskiej (zob. Kierlan, Walsh, 2018, s. 129-152; Otterbeck, Mattsson, Pastene, 2018, s. 267-286).

5) W Polsce muzykę metalową analizują w sposób naukowy badacze skupieni wokół inicjatywy dr. Jakuba Koska „Metal Studies” na Uniwersytecie Pedagogicznym w Krakowie. Spotkania naukowe są cyklicznym wydarzeniem organizowanym przez Ośrodek Badań nad Mediami w Krakowie, Katedrę Mediów i Badań Kulturowych Instytutu Filologii Polskiej Uniwersytetu Pedagogicznego w Krakowie oraz Szkołę Doktorską Nauk Społecznych i Humanistycznych Uniwersytetu SWPS. W październiku 2020 r., gdy miałem zaszczyt wystąpić po raz pierwszy przed ekspertami reprezentującymi różne dyscypliny naukowe, proponując opowieść o UBM, odbyła się czwarta edycja „Metal Studies”.

6) Nawiązania do historii BM (jako tła dla rozwoju UBM) oparłem na rozdziale szesnastym e-bookowej wersji książki Iana Christe The Sound of the Beast.

7) W odróżnieniu od Encyklopedii Metalu, sytuuję UBM jako podgatunek black metalu, a nie metalu jako takiego, ponieważ żywioł chrześcijańskiej muzyki UBM jest bezpośrednio skorelowany z black metalem. UBM nie istniałby bez BM. Black metal jest alter ego UBM i na odwrót. Chrześcijański metal blackowy jest bezpośrednią i jednoznaczną odpowiedzią na black metal satanistyczny i neopogański, jest jego fascynującą mutacją, ale oczywiście, o czym także wspomniałem, nie może być do niego redukowany.

8) Dane te ukazują, że istnieje potężna nadreprezentacja mężczyzn tworzących metal (twórczość tę uprawiają w 93\% mężczyźni, a tylko 7\% artystów to kobiety), kobiece zespoły czy artystki zasilające projekty muzyczne są nadal niestety mało obecne w muzycznym przemyśle. Metal jako gatunek muzyczny, a także UBM, nie jest oczywiście wyjątkiem pod względem tych feministycznych deficytów (zob. Such-Pyrgiel, 2018, s. 174).

9) Wyróżnienie trzech fal UBM oraz ram czasowych dla każdej z nich jest moją autorską propozycją opracowaną na podstawie danych zawartych w internetowej Encyklopedii Metalu. 
10) Jest to autorskie opracowanie działów tematycznych występujących w treściach utworów UBM, powstałe na podstawie autorskiej analizy danych (piosenek) umieszczonych w Encyklopedii Metalu.

11) Jako autor teorii zwrotu inkorporacyjnego (TZI) uważam, że problematyka triady inności „Swój-Obcy-Wróg” doskonale pasuje do socjologicznej analizy sytuacji chrześcijan reprezentujących UBM (zob. Korczyński, 2019). Wspominany znawca zagadnienia UBM - Markus Moberg - podobnie jak ja twierdzi, że chrześcijański metal ma podwójny dylemat: jest odrzucany zarówno przez „ortodoksyjnych” metalowców, jak i przez ortodoksyjnych chrześcijan. Przy czym Moberg poszerza horyzont, obejmując całościowo metalową kulturę, także tę stricte świecką (Moberg, 2012, s. 87-88, 97-98), ja z kolei skupiam się przede wszystkim na antagonizmie radykalizmów, $w$ tym przypadku fundamentalistycznych chrześcijan $\mathrm{z}$ jednej strony, a satanistów i neopogan, którzy wspólnie, niejako ręka w rękę, pozostają ze sobą w nieformalnym sojuszu, zwalczając UBM - z drugiej.

12) Warto tu wymienić najnowsze opracowania z zakresu socjologii muzyki (zob. bibliografia) Michała Cebuli, Marcina Choczyńskiego, Henryka Domańskiego, Katarzyny Drzewek, Izabeli Frankiewicz-Olczak, Wojciecha Hardy, Barbary Jabłońskiej, Piotra Lewandowskiego, Michała J. Lutostańskiego, Karoliny Messyasz, Szymona Pilcha, Dariusza Przybysza, Agaty Rozalskiej, Karoliny Szczepaniak, Jakuba Sokołowskiego, Artura Szareckiego, Katarzyny M. Wyrzykowskiej, Kingi Zawadzkiej. 
